KONTRIBUSIA, Vol 5, Issue 1, 2022

ISSN 2614-1582 E-ISSN 2614-1590

Published by Research and Community Development Center

\title{
Community Partnership Program (PKM) Procurement and Management Efforts of Vocational School Libraries August 17, 1945 According to the National Library Standards Agency (BSNP) of the Republic of Indonesia
}

\author{
Author \\ Ardianik (Orcid ID. 0000-0002-2591-7988) \\ Wahyu Widayati (Orcid ID. 0000-0003-4861-2105) \\ Correspondence \\ Faculty of Teacher Training and Education, Universitas Dr. Soetomo Surabaya \\ ardianik@unitomo.ac.id; wahyu.widayati@unitomo.ac.id
}

\begin{abstract}
:
Partners in the implementation of this community partnership program are SMK 17 Agustus 1945 which is located on Jalan Nginden Semolo no.44 Surabaya. The facilities owned are IT-based, it's just that the obstacles faced by schools in supporting the teaching and learning process, especially the facilities and convenience of libraries, have not met the national library standards. Based on the input of teachers and library staff as well as direct observations made by the service team, there are several problems, namely: 1) There is no arrangement of library material collections according to their field of knowledge; 2) There is no book cataloging in accordance with the field; 3) Inventory of library materials has not been managed properly and correctly, by providing a book slip for each book; 4) There is no circulation service yet, because officers are burdened with routine public relations activities and lack of library personnel; 5) There is no guidebook in managing library materials, officers have not used standard guidelines. There are two stages in implementing the solution that must be completed with partners, namely: 1) the planning stage which includes: coordination with library staff, teachers, and school principals as initial input, direct observation to obtain evidence related to initial input; 2) Implementation phase which includes: Arrangement and classification of library collections, cataloging library collections, inventory, making library circulation services, making manuals. The results of the community service activities concluded that there were significant differences before and after the procurement and management of the library. This is evident from the results of activities in the form of classification, the arrangement of library collections has been well realized, the room layout is neatly arranged, cataloging library collections, numbering and installation of slips have been installed properly, making library circulation services, and making library management manuals. manual has been realized. From a series of community service activities, it has a success rate of $100 \%$. This is shown from all activities that have been completely completed and the results can be enjoyed by students, teachers and visitors to the SMK 17 August 1945 Library and no less important for the sake of school accreditation.
\end{abstract}

Keywords: School Libraries, Library Management, Library National Standards.

\section{Introduction}

A partner in the implementation of this community partnership program is SMK 17 Agustus 1945 which is located on Jalan Nginden Semolo no.44 Surabaya. This educational institution was founded in 2002 by the Saraswati Education Management Association Foundation in Surabaya. With his vision, namely: "To make graduates of SMK 17 August 1945 Surabaya with
Received: 28 June 2021. Accepted: 27 December 2021.

global standards who are superior, competitive and have good character". The facilities owned by SMK 17 August 1945 are good and IT-based.

The accreditation value of SMK 17 August 1945 has reached the highest score, namely A, it's just that the supporting facilities in the teaching and learning process, especially library facilities and conveniences, have not met 
the national library standards. Based on the input of teachers and library staff who said that the library of SMK 17 August 1945 still needs to be addressed, especially in its administrative management. Based on direct observations made by the service team assisted by students as members team, the condition of the library does need to be quality of service and correct library administration.

These conditions indicate that the library standards of SMK 17 August 1945 still do not meet the ideal library standards. Because library administration is one of the main contributions in determining whether a library is ideal or not. According to (Zohriah, 2017) in the article "School Library Service Effectiveness", an ideal
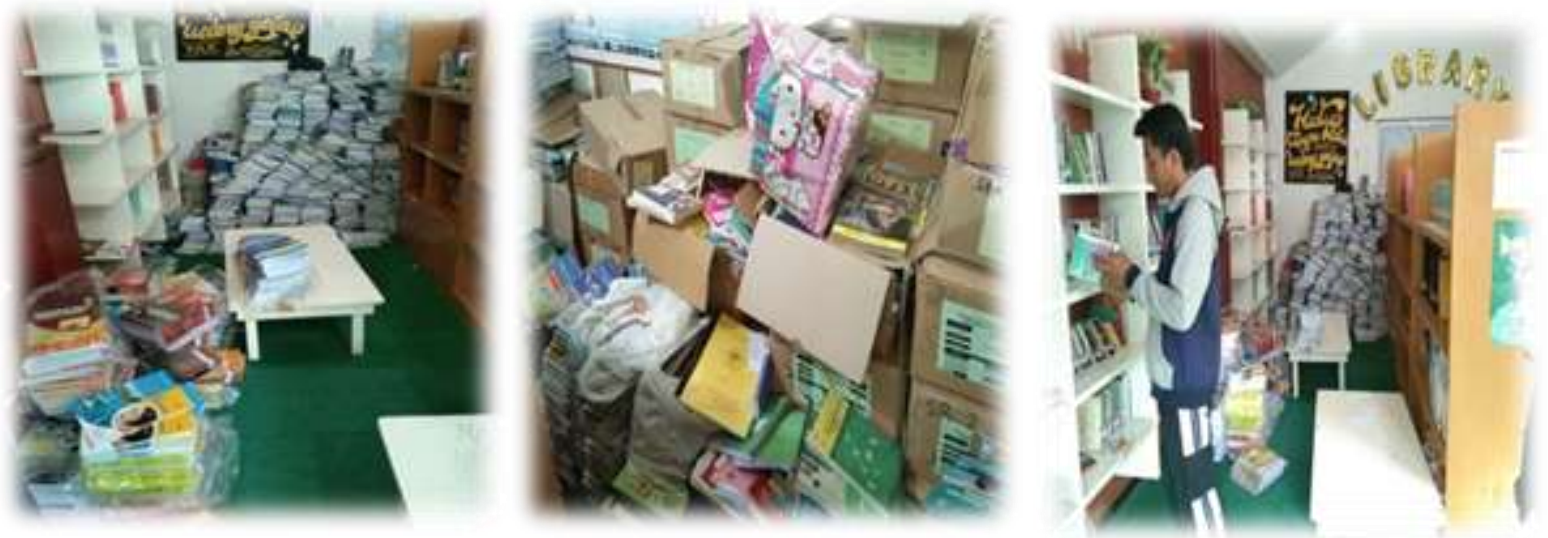

Figure 1. Photos of the Early State of Vocational High School Library August 17, 1945

improved, especially in its administration. There are several conditions found by the service team, including the absence of guest books, incomplete library inventory, unavailability of library catalogs, not installed book labels, incomplete library material collections, unclear book classification, irregular layout of cabinets and bookshelves, the service administration (circulation) is also not going well and there is no library management guidebook according to national standards.

Based on the above conditions which can be seen in Figure 1.1, the service team accompanied by students felt the need to carry out service, especially the procurement and management of the 17 August 1945 Vocational School library administration. The scope of service was directed at problems found by the service team through input from teachers, library staff and seeing the situation. Directly, this service can help library employees improve the library can adequately function as an information center for students as follows: 1) There is a strong institutional status of the library; 2) The organizational structure of the library is clear and runs well; 3) Has adequate space according to the number of students, is clean, and has sufficient lighting; 4) Having adequate reading places; 5) Has adequate library furniture; 6) Participation of the wearer (students and teachers) is good and active; 7) The type of collection reflects a good composition between textbooks and fiction books, namely $40 \%$ for text books, $30 \%$ for enrichment books, and 30\% for fiction books as well as varied book titles; 8) The collections that are owned are in accordance with the needs of the school curriculum; 9) Having management staff with adequate competence; 10) Organizing the collection regularly; 11) Supported by information and communication technology; 12) Orderly administration of the library which includes membership administration, 
administration of book and furniture inventory, borrowing, depreciation, book addition, and lending statistics; 13) Has a good information retrieval facility; 14) Has library regulations; 15) Have a clear and directed development program; 16) Having an information literacy (information literacy) program; 17) Has a reading interest development program among students;

18) Has a library partner program; 19) Conducts library promotion and socialization activities; 20) Library activities integrated with curriculum and learning activities; 21) Having a library budget on a regular basis; 22) There is cooperation with other schools; 23) The service is pleasant, and 24) There are school library hours integrated into the curriculum.

In law number 20 of 2003 concerning the national education system in chapter IX, article 35 , it is stated that the school library is one of the learning resources needed to support the learning process. Other learning resources include laboratory rooms, skills rooms, sports venues, and others. According to (Darmono, 2017) the school library is a place to store, process, and provide various written works, printed works, and recorded works that are carried out with a standard system to support school goals.

According to the library law of the Republic of Indonesia No.43 of 2007 (Anonim, 2007) chapter VII article 23 regarding the types of school libraries, it is as follows:

1. Each school / madrasah maintains a library that meets the national library by into taking account standards the national education standards.

2. The library as referred to in paragraph (1) is obliged to have a collection of textbooks designated as compulsory textbooks in the education unit concerned in sufficient numbers to serve students and educators.

3. The library as referred to in paragraph (1) develops other collections that support the implementation of the educational curriculum.
4. School / madrasah libraries serve students of equality education which is carried out within the respective educational unit.

5. School / madrasah libraries develop library services based on information and communication technology.

6. Schools / madrasahs allocate funds of at least $5 \%$ of the school / madrasah operational expenditures or goods expenditures excluding personnel expenditures and capital expenditures for library development.

As one of the educational facilities, the school library functions as a learning support for students and helps students and teachers to accelerate the achievement of educational goals (Artana, 2019). The school library must allow teachers and students to have the opportunity to expand and increase knowledge by reading the library materials needed in the teaching and learning process. Libraries should be an integral part of the learning system, no longer just a complement to the existence of a school. As one of the facilities in the learning process, the school library has the main function of education, storage, and preservation of library materials (Lubis \& Siahaan, 2018).

According to (Sonia \& Sobri, 2019) library functions, namely: 1) educational function, all existing facilities and facilities in the school library, especially the collections that it manages a lot to help students and teachers to learn and acquire knowledge; 2) informative function, striving to increase the provision of library collections in the form of books or nonbooks which provide information; 3) recreational function as a complement to the library so that users in the library feel entertained and comfortable with the additional facilities; 4) research and research functions, the school library collections owned can be used as reference materials to help carry out simple research activities; 5) administrative responsibility function, implementing standard operating procedures for library visitors, namely 
the service system for borrowing and returning books.

According to the Indonesian National Library Standards Agency (BSNP) Perpustakaan, issued in 2011, high school library standards include: collections, facilities and infrastructure, services, personnel, administration, management, organizing library materials, budget, maintenance, cooperation and integration with the curriculum. This standard applies to both public and private high school libraries.

In the law on libraries above, it is obligatory for senior high schools in Indonesia, both public and private, to organize libraries by observing guide lines national library standard. Law on Libraries No. 43 of 2007 is one of the basic foundations for organizing libraries in schools. Based on the National library standards set by the National Library Standards Agency (BSNP) of the Republic of Indonesia, one of the schools that did not meet the above standards was SMK 17 August 1945.

Referring to the situation analysis, priority issues were agreed upon with partners to be resolved during implementation. the community partnership program at SMK 17 Agustus 1945 is the procurement and management of library administration with the aim of improving library administration so that it can meet ideal library standards. Some of the problems that become the priority of the service team are as follows:

1) The library of SMK 17 August 1945 has no arrangement of library material collections according to their fields of knowledge, arrangement of shelves and books on shelves; 2) There is no book cataloging in the form of labeling each bookshelf according to its field; 3 ) Inventory of library materials has not been managed properly and correctly, so it needs to be addressed by providing a book slip for each book; 4) There is no circulation service (borrowing and returning books), because officers are burdened with routine public relations activities and lack of library personnel; 5) There is no guidebook in managing library materials, officers have not used standard guidelines, such as Dewey Decimal Classification (DDC) for classification, Angelo American Catalog Rules (AACR) for cataloging (Bangsawan, 2019).

With the background of the fact that the library is one part of the school that supports teaching and learning activities and is an integral part of the school curriculum system (Badrudin, 2019), the service team tries to provide solutions to several partner problems. With the hope, after the improvement, the quality and intensity of the SMK 17 August 1945 library will improve.

\section{Implementation Methods}

Based on the solutions offered and the results of discussions with partners, the problems that must be resolved with partners will be carried out in two stages, namely the planning stage and the implementation stage. The following is an explanation of the two stages:

\section{Planning}

Stage The planning stage in the implementation of this partnership program is:

a. The service team coordinates with library staff, teachers, and school principals who are responsible for library management.

b. The service team made observations at the SMK 17 August 1945 library. At this stage the goal to be achieved was to obtain evidence related to the initial input we received from teachers, librarians and school

principals as material for consideration in carrying out the service.

c. The Service Team prepares all the needs that will be needed during the implementation of the service program.

\section{The Implementation Stage}

Community Service Programis carried out in five stages, namely:

Arranging and classifying the Library Collection.

In this activity, the service team makes improvements in arranging material collections Library according to their respective fields of knowledge. The service team, assisted by students as team members, rearrange the books on the library shelves 

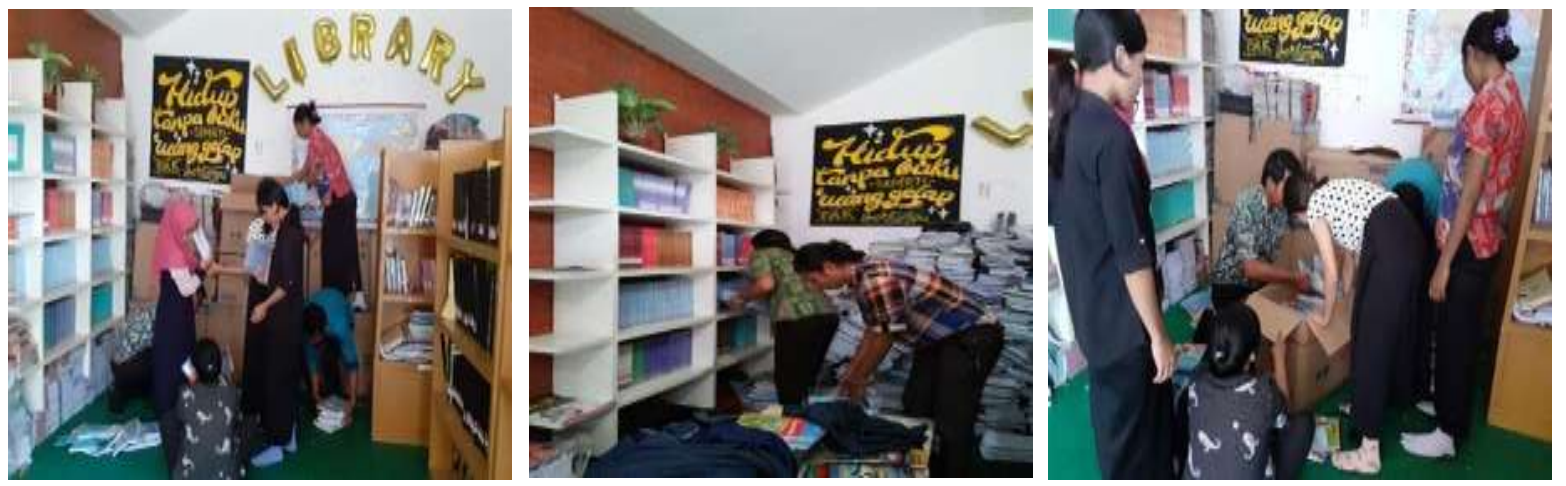

Figure 2. Photos During the Implementation of The Service Program In the Form of: Book Structuring, Shelf Structuring, Classifying.

and classify them according to their respective fields, and during the implementation of this activity the service team also made improvements in the arrangement of bookshelves and study desks that were not previously well organized.

\section{Library collection cataloging}

The service team and library staff made an agreement to create a manual catalog in the form of: numbering each book, placing a label on the shelf according to their field of knowledge so that teachers or students visiting the library will find it easier to find the book or material they want.

\section{Conducting Inventory}

The service team manages the SMK 17 August 1945 library better than before, by fixing and giving each book a slip to make it easier to collect, borrow and return books.

\section{Making Library Circulation Services}

The service team makes circulation services (visitor books, borrowed books, and returned books) because in the 17 August 1945 Vocational School library, circulation services are not running well where students or teachers who borrow or return books in the library do not fill in administration first because there is no provision of guest list book, loan list book, and return list book.

The community service team made this circulation service with the aim that the circulation process in the SMK 17 August 1945 library runs well so as not to make it difficult for library staff to calculate library statistical data each month.

\section{Making Guidebooks}

At the end of the implementation of this community service program, the community service team made a book classification and cataloging manual which would later be given to library staff to serve as a guide in managing good and correct library.

\section{Results Activity}

Of this community service programas a whole obtained the following results:

1. Arrangement and Classification of Library Collections

Arrangement and classification of collections in the SMK 17 August 1945 library went well. The library, which was not originally arranged, 

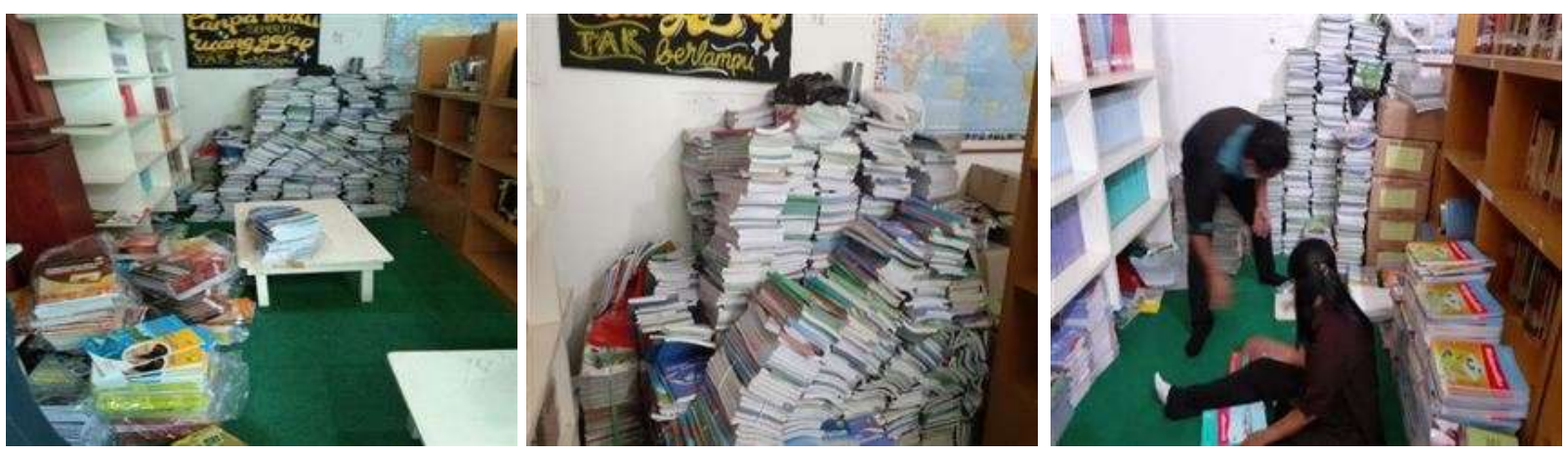

Figure 3. Photos of Library Conditions Before Program Implementation
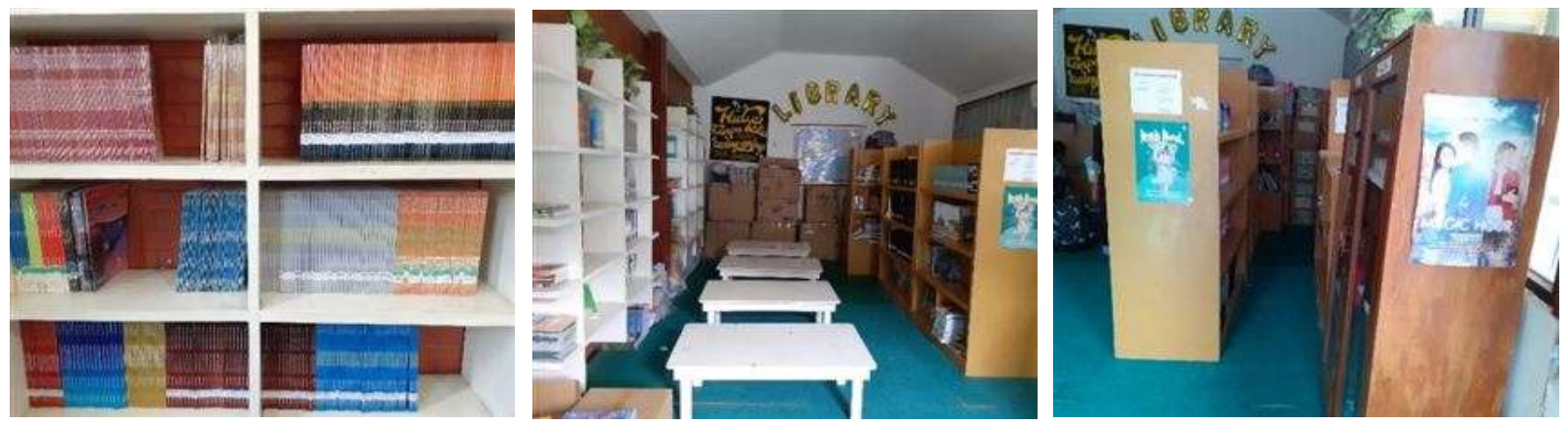

Figure 4. Photos of Library Conditions After Program Implementation

is finally organized properly, the books have been classified according to their respective fields. The layout of the bookshelves and study desks that were previously not well arranged becomes well-ordered.

\section{Library Cataloging}

Catalogs cataloging of collections in the SMK 17 August 1945 library has been well realized compared to before seen. The service team has installed a manual catalog in the form of numbering.
With the cataloging of library collections, it is easier for teachers or students to find the books they want.

\section{Conducting Inventory}

Conducting an inventory of the installation of slips on each book has been well realized. The service team has attached a slip to each book in the library. The purpose of installing this slip is so that students or teachers when borrowing books are more orderly in administration.
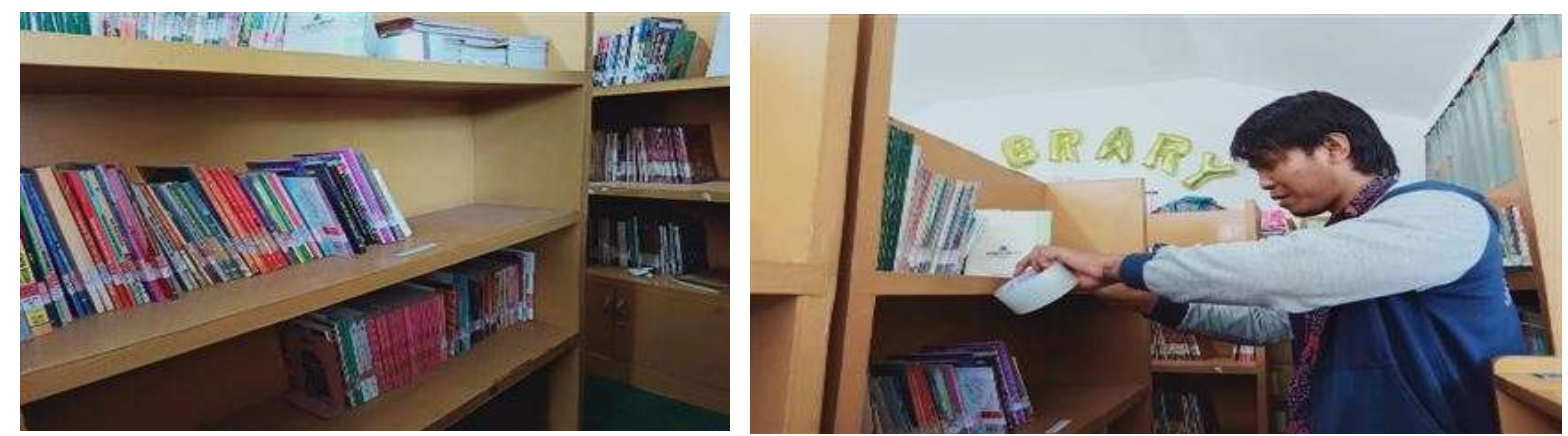

Figure 5 Photos Before Catalogue and Label Installation Process 


\section{Making Library Circulation Services}

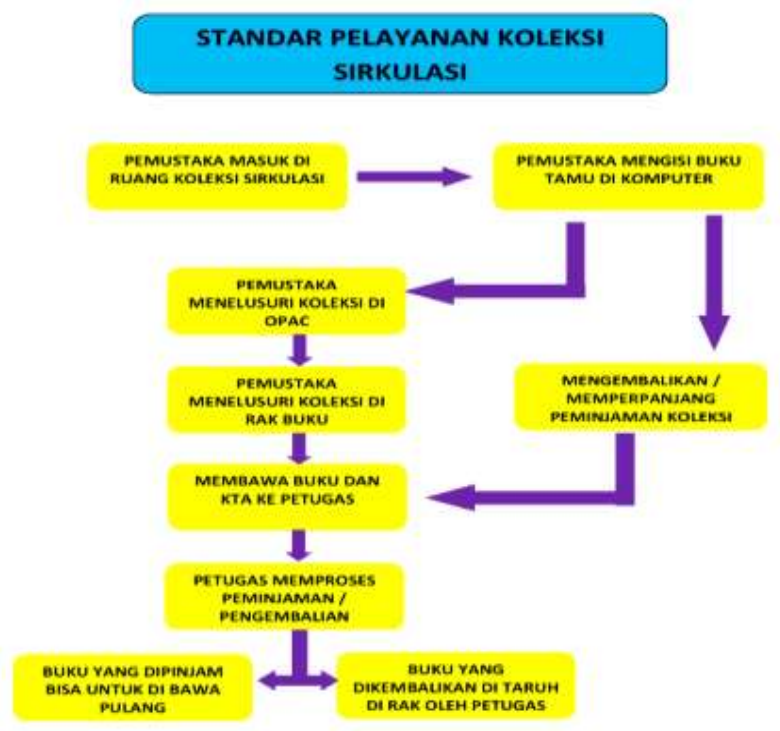

Figure 6. Circulation, Borrowing, and Returns

Explaining about library circulation services in the form of making visitor books, borrowing books, returning books and installing circulation charts at the entrance to the library have been well realized.

Previously, at the SMK 17 August 1945 library, there were no circulation service books in the form of visitor books, collection borrowing books and collection return books. With this activity, the service team has prepared the books.

5. Making Manual Library Management Manual.

Manual library management manual making has been well realized.

The guidebook contains national library standards for high school/equivalent, classification of library collections according to DDC (Dewey Decimal Classification) and AACR (Angelo American Catalog Rules).

\section{Conclusion}

From the results of the partnership program activities that have been carried out, it can be concluded that there are significant differences before and after PKM procurement and library management at SMK 17 August 1945. This is evident from the results of activities in the form of classification, arrangement of library collections has been realized properly, layout the room is neatly arranged, cataloging library collections, numbering and installation of slips have also been installed properly, the creation of library circulation services, and manual library management manuals have been realized.

From a series of activities this community partnership program has a success rate of $100 \%$. This is shown from all activities that have been completely completed and the results can be enjoyed by students, teachers and visitors to the SMK 17 August 1945 Library and it is no less important for school accreditation.

Good cooperation between partners and service teams is the main asset in the success of this activity. The successful implementation of this partnership program is strongly influenced by the active role of the service team and school partners of SMK 17 Agustus 1945 Surabaya. Partners have provided many information assistance

regarding problems experienced by employees regarding libraries, are willing to prepare equipment if needed by the service team in implementing this program, and are willing to provide advice after the program is complete for the continuation and success of this program.

Therefore, it is necessary to increase the trust and commitment of each party so that the goals can be achieved with satisfactory results and it is hoped that partners will maintain the existence of the library so that it is well maintained. 


\section{References}

Anonim. 2007. Undang-Undang No. 43 Tahun 2007 Tentang Perpustakaan. http://kepri.kemenag.go.id/file/undangUnd ang/rayk1391497505.pdf

Artana, I. K. 2019. Upaya mengoptimalkan peran perpustakaan sekolah melalui pengelolaan yang profesional. Acarya Pustaka, 6(1), 19. https://doi.org/10.23887/XXXXXX-XX0000-00

Badrudin, A. R. 2019. Manajemen Perpustakaan Sekolah dalam Merealisasikan Pengembangan Kurikulum 2013 di SMK Wiradikarya Ciseeng Bogor. Islamic Management, 02(01), 83-102.

Bangsawan, I. 2019. Panduan Penomoran Buku Menurut DDC. Kedai Pustaka Publisher Arus Bawah.

Darmono. (2017). Manajemen dan Tata Kerja Perpustakaan Sekolah. PT. Grasindo.

Lubis, H. A., \& Siahaan, A. T. A. 2018. Manajemen Perpustakaan dalam Meningkatkan Minat Baca Siswa Di MAN Kisaran. Al-Fatih: Jurnal Pendidikan Dan Keislaman, I(2), 203-231.

Perpustakaan, B. N. S. 2011. Standar Nasional Perpustakaan. In Standar Nasional Perpustakaan. BNSP.

Sonia, B., \& Sobri, A. Y. 2019. Perpustakaan Sebagai Pusat Sumber Belajar Untuk Mewujudkan Sekolah Yang Unggul. Jurnal Administrasi Dan Manajemen Pendidikan, 2(4), 188-193.

Zohriah, A. 2017. Efektivitas pelayanan perpustakaan sekolah. Tarbawi, 3(01), 102-110. 